\title{
Analysis of Capital Market and Economic Development in Nigeria: Time-Series Evidence from Nigeria 1981-2017
}

\author{
Uke Kalu Ejibe, Asemota Iyore
}

\begin{abstract}
A well-developed capital market creates a sustainable low-cost distribution mechanism for multiple financial products and services across the country. This study has sought to demonstrate an important role played by capital market in economic growth and development. To achieve this objective, an error correction model was estimated for economic growth in Nigeria, using Vector Error Correction techniques on an annual time series data spanning from 1981 to 2017. Our results were subjected to ADF Unit Root Test and it's stationary after first difference, which implies that they are integrated of order I(1) series at one percent significance level. The result of the normalized cointegrated series further reveals that market capitalization rate, total value of listed securities and number of deals are significant macroeconomic determinants factors of economic growth in Nigeria. It was then recommended that, Government through the Central Bank should introduce and implement favourable monetary policies that will increase the level and size of Market Capitalization in the Nigerian Capital Market, this increase will surely increase fund availability for desired investment which in turn will increase productivity of the Nation.
\end{abstract}

Index Terms - Capital Market, Economic Growth, and Market Capitalization variables.

\section{INTRODUCTION}

A well-developed capital market creates a sustainable low-cost distribution mechanism for multiple financial products and services across the country. This writing has sought to demonstrate an important role played by capital market in economic growth and development. Capital market enhances efficient financial intermediation. It increases mobilization of savings and therefore improves efficiency and volume of investments on economic growth and development. Njemcevic, (2017). Capital market provides equity capital and infrastructure development capital that has strong socio-economic benefits through development of roads, water and sewer systems, housing, energy, telecommunications, public transport, etc. These projects are ideal for financing through capital market via long dated bonds and asset backed securities. Infrastructure development is a necessary condition for long-term sustainable growth and development. In addition, capital market increases the efficiency of capital allocation by ensuring that only projects which are deemed profitable and hence successful attract

Uke Kalu Ejibe, Economics Department, Abia State University, Uturu Asemota Iyore, Department: Entrepreneurship, Faculty of Management Sciences, University of Benin, Benin City funds. This will, in turn, improve competitiveness of domestic industries and enhance ability of domestic industries to compete globally, given the current momentum towards global integration. The result will be an increase in domestic productivity which may spill over into an increase in exports and, therefore, economic growth and development, Taiwo and Ogunji(2018).

\section{A. Statement of problem}

The problem facing the Nigerian Capital Market is the mobilization and efficient allocation of capital for investment purposes, Ogege and Ezike, (2012). The market puts in place structures for the mobilization of savings from numerous surplus economic units for the purposes of the productive process and thus enhances economic growth and development.

However, because of certain problems inherent in or affecting the market, the performance of the capital market has always been questioned. Some of these problems include stringent listing conditions especially in the first and second tier markets. There is also lack of awareness by the investing public, leading to low activity and insufficient funds in the market arising from the buy and hold attitude of majority of investors. Other problems are poor economic conditions making companies not to perform well in terms of product availability and dividend payment.

\section{B. Objectives of the Study}

The main objective of this study is to examine therole capital market played on economic growth in Nigeria from 1981 to 2017.

1. To assess the contribution of capital market on Nigeria economic growth.

2. To determine the impact of all Market Capitalization variables on economic growth in Nigeria.

\section{Research Questions}

The following research questions have been constructed to guide and sharpen the study:

1. What extent does capital market have on economic development in Nigeria?

2. What influence does Market Capitalization variables have on economic growth in Nigeria?

\section{Research Hypotheses}

The following hypotheses have been stated in their null forms: 
1. $\mathrm{HO}_{1}$ : Capital Market has no significant relationship on economic growth in Nigeria.

2. $\mathrm{HO}_{2}$ : There is no significant impact between Market Capitalization variables and economic growth in Nigeria respectively.

\section{E. SIGNIFICANCE OF THE STUDY}

The researcher sightseen the empirical usefulness of capital market on Nigerian economic growth. Nevertheless the scope of the research was restricted to the capital market; it is as a result of these that the consideration of the market provides a broad understanding of the operations of the capital market in Nigeria. It leads to the contribution of existing literature on the subject matter by scrutinizing empirically the part, which the capital market plays in the economic growth and development of the country. The focal significance of this study is that it will offer policy recommendations to policy-makers on ways to advance operations and accomplishments of the capital market in Nigeria.

\section{REVIEW OF RELATED LITERATURE}

To find out how Capital market development has directly affected economic growth, an empirical review of a host of research studies are discussed here. The structure first starts with an overview of capital market development, as well as some theoretical viewpoints, primarily in relation to its activity indicators like, value and volume of transactions, volatility, liquidity, listed securities and index returns; then next is economic growth theories and empirical evidences, and finally an evaluation of the evidences of the relationship of both concepts. A summary is provided at the end to amalgamate the findings and provide a direct answer to the first objective and research question proposed in the Background.

\section{A. Conceptual frame work}

The essence of the capital market is to channel free capital funds in one economy into real sector projects that would spur economic growth Beck, Mattias and Giovanni (2006).

Capital market increases the proportion of long-term savings (pensions, funeral covers, etc.) that is channeled to long-term investment. Capital market enables contractual savings industry (pension and provident funds, insurance companies, medical aid schemes, collective investment schemes, etc.) to mobilize long-term savings from small individual household and channel them into long-term investments. It fulfills the transfer function of current purchasing power, in monetary form, from surplus sectors to deficit sectors, in exchange for reimbursing a greater purchasing power in future. In this way, capital market enables corporations to raise capital/funds to finance their investment in real assets.

However, Njemcevic, (2017) suggested that capital market promotes public-private sector partnerships to encourage participation of private sector in productive investments. The need to shift economic development from public to private sector to enhance economic productivity has become inevitable as resources continue to diminish. It assists the public sector to close resource gap, and complement its effort in financing essential socio-economic development, through raising long-term project based capital. It also attracts foreign portfolio investors who are critical in supplementing the domestic savings levels. It facilitates inflows of foreign financial resources into the domestic economy.

\section{Capital Market Development and Economic Growth}

Recent empirical research linking capital market development and economic growth suggests that capital market enhances economic growth and development. Countries with well-developed capital markets experience higher economic growth than countries without. Evidence indicates that, while most capital markets in African countries are relatively underdeveloped, those countries which introduced reforms that are geared towards development of capital markets have been able to grow at relatively higher and sustainable rates. Stock market ensures the proper environment for obtaining more financial resources to develop investment projects and sharing risks, and, sometimes, they are seen as an agent who hurts economic development due to their susceptibility market failure, Lenuţa (2012).

A study in 2011 showed that South Africa, the country whose capital market is the largest and most developed in Africa, in terms of market capitalization and trading volume, has been growing significantly since 2000. Its average per capita real GDP over the last 8 years has been at $3.2 \%$. Countries like Egypt, Ghana, Tanzania, Botswana and Mauritius, whose capital markets have been developing recently, were able to realize average per capita growth rates of more than $2.8 \%$ for the past 8 years. However, some economies which did not have formal or effective capital market like Lesotho, Seychelles and Ethiopia could not manage to realize average per capita growth rates above 2.7 $\%$ over the past 8 years. Even those countries with small and less developed capital market like Swaziland and Uganda did not manage to realize average per capita growth rates above $2.7 \%$ during the past 8 years, CBL Economic Review, (2009).

Economic development in a modern economy hinges on an efficient and effective financial sector that pools domestic savings and mobilizes capital for productive projects. Absence of effective capital market could leave most productive projects which carry developmental agenda unexploited. Capital market connects the monetary sector with the real sector and therefore facilitates growth in the real sector and economic development, Kolapo and Adaramola, (2012).

\section{B. Theoretical frame work}

Worapot (1996), maintain that theory of Capital Markets is to revisit the relevant theory and evidence regarding the informational efficient capital markets. It explores the normative theory of perfect capital markets, the stochastic notion of random walk, the martingale theory, and various forms of market efficiency under the efficient markets hypothesis (EMH).

Merton (1985) has introduced the rational market hypothesis to refer to the relationship between market prices 
and information. Most of the literature on its study is concerned with empirical tests of the hypothesis of informational efficiency.

\section{The Random Walk Hypothesis}

Several statisticians had noted that security prices tend to fluctuate randomly in the manner that security returns exhibit a very low degree of serial correlation. If prices reflect all currently available information and change to their new equilibrium values immediately only on the receipt of new information, then all price changes will be uncorrelated. Bachelier (1900) uses statistical methods to analyze gambling and later applied them to analyze returns on stocks, bonds, futures, and options. Osborne (1964), in his paper Brownian Motion in the Stock Market formalizes that stock price follows a random walk when he develops its assumptions using the Brownian motion which is equivalent to the movement of a particle in a fluid.

\section{The Martingale Hypothesis}

Fama (1970) suggests that a capital market is a martingale, i.e., fair game. He implicitly assumes that all individuals have the same information functions and, at least conditional on the information under consideration, they share the same beliefs. This allows him to use the terms efficient capital marketswithout any ambiguity. The fair game means that information cannot be used to profit in the market. It requires that traders be rational in order to achieve general price equilibrium. It does not require independence through time or accept only the independently and identically distributed (IID) observations. If returns are random, then markets are efficient. But, when markets are efficient, the returns are not necessarily random.

\section{Theory of capital and investment}

Irving Fisher's theory of capital and investment was introduced in his Nature of Capital and Income (1906) and Rate of Interest (1907), although it has its clearest and most famous exposition in his Theory of Interest (1930). Of concern is what he called his "second approximation to the theory of interest" Fisher, (1930), which sets the investment decision of the firm as an inter-temporal problem.

In his theory, Fisher assumed (note carefully) that all capital was circulating capital. In other words, all capital is used up in the production process, thus a "stock" of capital K did not exist. Rather, all "capital" is, in fact, investment. Friedrich Hayek (1941) would later take him to task on this assumption - in particular, questioning how Fisher could reconcile his theory of investment with the Clarkian theory of production which underlies the factor market equilibrium.

\section{Empirical review}

Researchers in their empirical works use secondary capital market ratios (market capitalization as a percentage of GDP, securities trade as a percentage of GDP, and securities trade as a percentage of market capitalization) to measure the development of capital market as a whole, Njemcevic, (2017).

Using Indian stock market indicators (liquidity, volume of transactions, volatility), Deb and Mukherjee, (2008), on their part, carried out a time series analysis and concluded that between real GDP growth and market capitalization is a bidirectional causality, but from capital market activity and real GDP growth exists a unidirectional relationship. Liquidity, as a stock market indicator, along with a sound and developed financial banking system, play a key role in accelerating economic growth, Levine, (1997), emphasized the impact of stock markets on economic growth by increasing capital investments liquidity, assuming that a higher degree of liquidity will allow savers to sell their shares easily, concluding that "stock market development does not represent a financial elixir for economic growth". Singh, (1997) view is often seen as an intermediary in generating positive countries, Atje and Jovanovic, (1993) showed the existence of a correlation between economic growth and the stock market value traded divided by GDP, identifying the fundamental channels through which economic growth can be influenced: liquidity, risk diversification, corporate governance, and acquisition of information.

Ogege and Ezike, (2012), they centered their findings on the role of the Nigeria capital and economic development. The capital market is primarily established to boast the industrial growth and economic development of Nigeria economy by mobilizing long-term funds and capital formation for investment and productive purposes. Using time series data from 1971-2010 and applying the Engle-Granger and Johansen method of co-integration in a VECM setting estimation technique. The results revealed that in the long run, the Nigerian capital market positively and significantly influence economic development. We therefore recommend that government should put more effort in developing an active new issues market by encouraging more floatation of new issues and create stable environment for business.

Enekwe, Eziedo and Agu (2016), identified Capital Market as an institution that contributes to the socio-economic growth and development of emerging economies. Due to the recent financial crises, the researcher cannot be enabling to investigate the extent to which capital market has affected the economic growth in Nigeria. The primary objective of this study is to examine the effect of the Nigerian capital market on the economic development in Nigeria. The economic growth was proxy by Gross Domestic Product (GDP) while the capital market variables considered include; market capitalization (MCAP), Number of listed securities (NLS), and Total value of securities traded (TVST). Three research questions and six hypotheses were raised in the course of this research. The Ex-post facto research design was used for this study. Secondary data was obtained from the annual report and financial statement from Nigerian stock exchange and central bank of Nigeria over a period of 30 years (1981-2012) and was analyzed using descriptive statistics, Pearson correlation and multiple regressions. The findings indicate that economic growth is significantly influenced by only MCAP. The factor that does not significantly influence economic development is, NLS and TVST. This is a clear indication that the capital market is a tool for economic development of the country. The evidence from this study reveals that the activities in the capital market tend to impact positively on the economy but not to the extent it is supposed 


\section{Analysis of Capital Market and Economic Development in Nigeria: Time-Series Evidence from Nigeria 1981-2017}

to. It is recommended therefore that the regulatory authority should introduce ICT policies to encourage more companies to access the market and also be more proactive in their surveillance role in order to check sharp practices which undermine market integrity and erode investors' confidence.

\section{Methodology}

The core of any research lies on its methodology since the acceptability and reliability of the findings depends on the appropriateness of the models specified and the analytical tools employed. When models are wrongly or even rightly specified with inappropriate methods applied to their analysis, the consequences will be "spuriosity" of results and hence misleading conclusions, Okpara (2010).

\section{A. Source of Data}

The model for the study is specified to examine the influence of capital market on economic growth in Nigeria. The data were extracted from Central Bank of Nigeria Statistical Bulletins, Annual Reports and Accounts of the Nigerian stock exchange within the period of $1981-2017$.

\section{B. Model Specification}

In measuring the impact of the capital market on economic growth, we adopted the convectional method of using their proxies. Thus capital was proxied by the Total Market Capitalization (TMCAP), Total Number of Deals (NDI) and Total Value of Stock (TVS), while economic growth was proxied by Gross Domestic Product (GDP).The study adopted the statistical method of multiple regression approach in line with that applied by Njemcevic, (2017) and Enekwe, Eziedo and Agu, (2018). Their studies infer that capital market indices significantly influence economic growth in Nigeria. Nevertheless, we made some adaptations to suit our study.

The functional relation of the model is given as:

$\mathrm{GDP}=\mathrm{f}(\mathrm{TMC}, \mathrm{NDI}, \mathrm{TVS})$

The model is specified as follows:
$\mathrm{GDP}=\beta 0+$
$\beta_{1}$ TMCAP+

$\beta_{2} \mathrm{NDI}+$

$\beta_{3}$ TVS+

Where: GDP=Gross Domestic product

TMCAP $=$ Total Market Capitalization

NDI $=$ Total Number of Deals

TVS=Total value of stock

$\beta 0, \beta_{1}, \beta_{2}$ and $\beta_{3}=$ constant parameters and $\mu=$ the error term

\section{Method of Data Analysis}

The statistical technical analyses of ordinary least square technique (OLS) were used. This technique was chosen as it depicts the stationarity of our variables. The following techniques of estimation were employed in carrying out the research.

\section{Unit Root Test (ADF Test)}

The Augmented Dickey-Fuller (ADF) test was used to determine the stationarity of our variable. This help to determine the order and level of difference stationary of the variables on the first order autoregressive process AR (1). The null hypothesis is that there is no unit root. The decision rule is that; if the ADF test statistic is greater than the 5 per cent critical value, we accept the null hypothesis i.e the variable is stationary, but if the ADF test statistic is less than 5 per cent critical value i.e the variable is non-stationary, then we reject the null hypothesis and go ahead to difference once; if the variable does not become stationary at first difference, we difference twice. However it is expected that the variable become stationary at first difference, Dickey and Fuller, (1979). The Augmented Dickey-fuller test (ADF) was used to handle the problem of data stationarity.

\section{Co-integration test}

After the test for the order of integration, the researcher test for co-integration. This test is used to check if long run relationship exists among the variables in our models, Ogundipe and Alege, (2013). The test was carried out using the Johansen co-integration technique.

\section{Error Correction Model Test}

The presence of co-integration forms the basis for error correction model specification. The error correction model (ECM) was first used by J.D. Sargan and later popularized by Engle and Granger, Gujarati, (2013). It is used to tie the short-run behavior of the dependent variable to its long-run value.

\section{DATA ANALYSIS AND FINDINGS}

\section{A. OLS Regression Results}

The Estimated Model for this research study is given below:

RGDP $=0.911713 *$ LOGTMCAP $-0.051519 *$ LOGNDI $-0.116737 *$ LOGTVS +4.847558

The Table below shows the analysis of the result of the data used in the study. The method of analysis employed is the Ordinary Least Square (OLS).

\section{B. Unit Root Test Result}

Literature has established that most time series variables are not stationary. Therefore, using nonstationary variables in the model might lead to spurious regression that cannot be used for precise prediction. Gujarati, (2003). Hence, our first step is to examine the characteristics of the time series data used for estimation of the model to determine whether the variables have unit roots, that is, whether it is stationary and the order of integration. The Augmented Dickey-Fuller test were used for this purpose. A variable is considered stationary if the absolute ADF value is higher than any of the absolute Mackinnon values. 
Table 1: Unit Root Test Summary Statistics (ADF Unit Root Test Results)

\begin{tabular}{|c|c|c|c|c|c|}
\hline Variable & $\begin{array}{l}\text { ADFstatist } \\
\text { ic }\end{array}$ & $\begin{array}{l}\text { Critical } \\
\text { Values }\end{array}$ & $\%^{\text {Sig }}$ & $\begin{array}{l}\text { Lagged } \\
\text { diff }\end{array}$ & $\begin{array}{c}\text { Order } \\
\text { Integration }\end{array}$ \\
\hline LGDP & -3.157453 & -3.632900 & $1 \%$ & I & I \\
\hline${ }_{\mathrm{P}}$ LTMCA & -4.584342 & -3.632900 & $1 \%$ & I & I \\
\hline LNDI & -5.924009 & -3.632900 & $1 \%$ & I & I \\
\hline LTVS & -5.441314 & -3.632900 & $1 \%$ & I & I \\
\hline
\end{tabular}

From the table above the results of ADF unit root tests are presented in table 2 above, suggests that the variables of the test indicate non-stationary at levels. However, these variables were stationary after first difference, which implies

\section{Cointegration Test}

that they are integrated of order I(1) series. Given the unit root properties of the variables, therefore, we proceed to test for actual number of cointegration equations that exist among the variables by using Johasen cointegration test.

Table 2: Unrestricted Cointegration Rank test

\begin{tabular}{|c|c|c|c|c|}
\hline \multicolumn{5}{|c|}{ Unrestricted Cointegration Rank Test (Trace) } \\
\hline Hypothesized & & Trace & 0.05 & \\
\hline No. of CE(s) & Eigenvalue & Statistic & Critical Value & Prob.** \\
\hline None * & 0.669496 & 62.79337 & 47.85613 & 0.0011 \\
\hline At most 1 & 0.353538 & 26.25790 & 29.79707 & 0.1211 \\
\hline At most 2 & 0.177708 & 11.86194 & 15.49471 & 0.1637 \\
\hline At most $3 *$ & 0.151083 & 5.405186 & 3.841466 & 0.0201 \\
\hline \multicolumn{5}{|c|}{$\begin{array}{l}\text { Trace test indicates } 1 \text { cointegrating eqn }(\mathrm{s}) \text { at the } 0.05 \text { level } \\
* \text { denotes rejection of the hypothesis at the } 0.05 \text { level } \\
* * \text { MacKinnon-Haug-Michelis (1999) p-values }\end{array}$} \\
\hline \multicolumn{5}{|c|}{ Unrestricted Cointegration Rank Test (Maximum Eigenvalue) } \\
\hline Hypothesized & & Max-Eigen & 0.05 & \\
\hline No. of $\mathrm{CE}(\mathrm{s})$ & Eigenvalue & Statistic & Critical Value & Prob.** \\
\hline None * & 0.669496 & 36.53548 & 27.58434 & 0.0027 \\
\hline At most 1 & 0.353538 & 14.39595 & 21.13162 & 0.3334 \\
\hline At most 2 & 0.177708 & 6.456758 & 14.26460 & 0.5553 \\
\hline At most $3 *$ & 0.151083 & 5.405186 & 3.841466 & 0.0201 \\
\hline
\end{tabular}

Max-eigenvalue test indicates 1 cointegrating eqn(s) at the 0.05 level

$*$ denotes rejection of the hypothesis at the 0.05 level

**MacKinnon-Haug-Michelis (1999) p-values

Unrestricted Cointegrating Coefficients (normalized by $b^{\prime * S 11 * b=I) ~}$

The presence of long run equilibrium relationship among

The trace test and the Max-eigenvalue indicate that there is cointegration at the 0.05 level, this denotes rejection of the hypothesis at the 0.05 level, implying there are long run equilibrium relationship among our variables the variables as found from the Johansen co integration led to the application of VECM. With this approach, both the long run equilibrium and short run dynamic relationships associated with variables under study is established.

\section{Vector Error Correction Mechanism (VECM)}

\begin{tabular}{lcccc} 
Error Correction: & \multicolumn{3}{c}{ Table 3: VECM } \\
& $\mathrm{D}(\mathrm{LOG}(\mathrm{GDP}))$ & $\mathrm{D}(\mathrm{LOG}(\mathrm{TVS}))$ & $\mathrm{D}(\mathrm{LOG}(\mathrm{TMCAP}))$ & $\mathrm{D}(\mathrm{LOG}(\mathrm{NDI}))$ \\
\hline \hline CointEq1 & 0.163409 & 0.310116 & 0.093962 & -0.291062 \\
& $(0.04131)$ & $(0.25839)$ & $(0.13496)$ & $(0.20658)$ \\
& {$[3.95572]$} & {$[1.20020]$} & {$[0.69621]$} & {$[-1.40892]$} \\
& & & & \\
$\mathrm{D}(\mathrm{LOG}(\mathrm{GDP}(-1)))$ & -0.135064 & -0.498766 & 1.196761 & 0.446073 \\
& $(0.23178)$ & $(1.44979)$ & $(0.75726)$ & $(1.15914)$ \\
& {$[-0.58271]$} & {$[-0.34403]$} & {$[1.58039]$} & {$[0.38483]$} \\
& 0.114608 & 0.168924 & -0.070077 & -0.205709
\end{tabular}


D(LOG(TVS(-1)))

$\begin{array}{lcccc} & (0.04997) & (0.31255) & (0.16325) & (0.24989) \\ & {[2.29362]} & {[0.54047]} & {[-0.42926]} & {[-0.82321]} \\ \text { D(LOG(TMCAP(-1))) } & & & & \\ & 0.031058 & 1.438214 & 0.004624 & 0.448600 \\ & (0.08060) & (0.50412) & (0.26331) & (0.40305) \\ & {[0.38535]} & {[2.85292]} & {[0.01756]} & {[1.11301]} \\ \text { D(LOG(NDI(-1))) } & & & & \\ & -0.088829 & -0.594262 & -0.018571 & 0.117240 \\ & (0.05721) & (0.35786) & (0.18692) & (0.28612) \\ \text { C } & {[-1.55260]} & {[-1.66059]} & {[-0.09935]} & {[0.40976]} \\ & & & & \\ & \mathbf{0 . 2 1 1 1 2 9} & \mathbf{0 . 3 2 6 2 0 3} & \mathbf{0 . 0 1 8 7 4 6} & \mathbf{- 0 . 1 7 0 1 0 8} \\ & (0.05073) & (0.31734) & (0.16575) & (0.25372) \\ & {[4.16148]} & {[1.02794]} & {[0.11310]} & {[-0.67046]} \\ \text { R-squared } & & & & \\ \text { Adj. } \text { R-squared } & & & & \\ \text { Sum sq. resids } & 0.820835 & 0.611172 & 0.952189 & 0.793185 \\ \text { S.E. equation } & 0.753649 & 0.465362 & 0.934261 & 0.715629 \\ \text { F-statistic } & 2.67 \mathrm{E}+12 & 67438332 & 2.83 \mathrm{E}+11 & 14721028 \\ \text { Log likelihood } & 333504.6 & 1676.285 & 108563.4 & 783.1834 \\ \text { Akaike AIC } & 12.21723 & 4.191551 & 53.10906 & 10.22730 \\ \text { Schwarz SC } & -474.7147 & -294.7501 & -436.5557 & -268.8772 \\ \text { Mean dependent } & 28.51263 & 17.92648 & 26.26799 & 16.40454 \\ \text { S.D. dependent } & 28.96156 & 18.37541 & 26.71691 & 16.85347 \\ & 27529.62 & 673.8882 & 37420.52 & 1607.096 \\ & 671930.7 & 2292.544 & 423419.1 & 1468.659\end{array}$

The existence of co integration among the variables as indicated above presents an evidence of long-run economic relationship among the variables. This implies that, vector error correction model is suited for further analysis. It captures both the long run equilibrium and short run dynamic relationships associated with the above results.

\section{A. Discussion of Results}

In table 3, the result shows our variables indicate that there is cointegration at 5 percent significance level. It is therefore statistically significant. The significance of the error correction model provides further confirmation to the co integration evidence, giving the impression of a long run movement between economic growth and the explanatory variables. Implying that in the incidence of the presence of external shock resulting to disequilibrium of the system, the model can still converge with time to its normal state with a relatively average speed of adjustment of 16.34 percent per time.

Our finding in table 1 shows that there is a positive relationship between GDP and Total market capitalization (LOGTMCAP). However, Number of Deal (LOGNDI) and $\log$ total value of stock (LTVS) are negatively related to gross domestic product. Findings from the study are consistent with previous studies such as Ogege and Ezike, (2012), Taiwo and Ogunji, (2018), Enekwe, Eziedo and Agu (2016), Taiwo, Adedayo, and Evawere (2016). The model has high coefficient of determination seen from R-squared of $99 \%$ and Adjusted R of $99 \%$ of the total variation in Gross Domestic Product.The implication of this is that the model has goodness of fit.
The result of the co integrated relationship reveals a significant relationship between total value of listed Stock (TVS) and Number of deals (NDI) and economic growth; with market capitalization having a direct effect on economic growth in Nigeria while that of total value of listed Stock (TVS) and Number of deals (NDI) in the market is inverse. This signifies that higher market capitalization increases the ability of firms to raise capital in order to increase investment spending and expand production of goods and services and this translates to higher economics growth in the long run. Similarly, increase in total value of listed Stock (TVS) and Number of deals (NDI) will significantly increase the volume of credit availability and further facilitate easy access to funds and investment. Therefore, the higher the physical capital made available for investors, the greater the likelihood of attracting prospective local and international investors that will boast capital investments within the economy.

The negative impact of total value of listed Stock (TVS) and Number of deals (NDI) traded ratio on economic growth may be due to the issues involved in trading shares such as high transaction costs, delay in the issuance of shares certificate to mention just few and that of labor force participation can be attributed to the high level of low skilled and semi-skilled labor that dominated the informal sector which actually account for a larger proportion of economic activities in Nigeria. 


\section{CONCLUSION AND RECOMMENDATION}

\section{A. Conclusion}

Our research has provided the contribution of capital market to economic growth and it was found to have a significant impact on the economy. Using multiple regression analyses to model development, the study estimates the relationship between four explanatory variables; market capitalization, total new issues, volume of transaction and listed equities and one explained variable, Gross Domestic Product, by means of the ordinary least square technique. This suggests that for a significant growth to be achieved in an economy, the main focus of policy makers should be on measures to promote growth in the stock market. This is a very pertinent and prerequisite consideration for any economy desiring increase rapid economic growth.

\section{B. Recommendations}

\section{Recommendations}

These studies made three recommendations based on our findings.

1. Government through the Central Bank should introduce and implement favourable monetary policies that will increase the level and size of Market Capitalization in the Nigerian Capital Market, this increase will surely increase fund availability for desired investment which in turn will increase productivity of the Nation.

2. Secondly, as observed the total listed equities in the NSE are still very low Therefore, to increase the number of listed companies there is need to ensure stable macroeconomic environment, to encourage foreign multinational companies or their subsidiaries to be listed on the Nigerian stock exchange and also to improve the trading system in order to increase the ease with which investors can purchase and sell shares.

\section{REFERENCES}

[1] Atje, R., \& Javanovic B. (1993). Stock markets and development. European Economic Review,37, 632-640

[2] Beck, Thorsten, Mattias Lundberg, and Giovanni Majnoni. ( 2006). "Financial Intermediary Development and Growth Volatility: Do Intermediaries Dampen or Magnify Shocks?" Journal of International Money and Finance 25 (7): 1146-67. doi:10.1016/j.jimonfin.2006.08.004.

[3] Fama, Eugene F. (1965). "The Behavior of Stock-Market Prices". The Journal of Business 38 (1): 34- 105.

[4] Deb, Soumya Guha \& Mukherjee, Jaydeep (2008). Does Stock Market Development Cause Economic Growth? A Time Series Analysis for Indian Economy. International Research Journal of Finance and Economics, ISSN 1450-2887 Issue 21 (2008).

[5] Gujarati, D.N. (2003) Basic Econometrics. 4th Edition, McGraw-Hill, New York.

[6] Lenuța Carp (2012), Can Stock Market Development Boost Economic Growth? Empirical Evidence from Emerging Markets in Central and Eastern Europe, Procedia Economics and Finance, Volume 3, 2012, pp. $438-444$

[7] Levine, Ross (1997). Financial Development and Economic Growth: Views and Agenda, Journal of Economic Literature, 35, 688-726.

[8] Lenuta Carp, (2012), THE IMPACT OF THE ECONOMIC CRISIS ON THE DYNAMIC OF INTERNATIONAL FDI, CES Working Papers, 4(1), (1), 35-43

[9] Kolapo, F.T. and Adaramola, A.O. (2012) The Impact of the Nigerian Capital Market on Economic Growth (1990-2010). International Journal of Development Societies, 1, 11-19.
[10] Taiwo, Muritala \& Ogunji, Morufat. (2018). Does the Capital Market Spur Economic Growth? Evidence from Nigeria. 11. 10.17323/j.jcfr.2073-0438.11.1.2017.90-99.

[11] Ogege, Samson \& E Ezike, John. (2012). The Nigerian Capital Market and Economic Development: A Critical Appraisal. International Business Research. 5. 10.5539/ibr.v5n8p228.

[12] Okpara, Godwin. (2010). Asymmetric Information and Dividend Policy in Emerging Markets: Empirical Evidence from Nigeria. International Journal of Economics and Finance. 2. 10.5539/ijef.v2n4p212.

[13] Singh, A. 1997, Financial Liberalization, Stock Markets and Economic Development, The Economic Journal, Vol. 107, p. 771782

[14] Enekwe, Chinedu Innocent; Eziedo, Kenneth Nnagbogu; Agu, Charles Ikechukwu.( 2018) Effect of Capital Market on Economic Growth in Nigeria. GOUNI Journal of Management and Social Sciences, [S.1.], v. 4 , n. 1 , p. 33-46,

[15] Njemcevic, F. (2017). Capital Market and Economic Growth in Transition Countries: Evidence from South East Europe. Journal of International Business Research and Marketing, 2(6), 15-22. 